\begin{tabular}{|c|c|c|c|c|c|}
\hline \multirow{3}{*}{ group } & \multirow{3}{*}{ 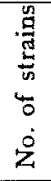 } & \multicolumn{4}{|c|}{ media used } \\
\hline & & \multirow{2}{*}{ Koji extract } & \multicolumn{2}{|c|}{ dextrose-bouillon } & \multirow{2}{*}{$\begin{array}{c}\text { dextrose } \\
\text { yeast water } \\
\text { pH } 4.3\end{array}$} \\
\hline & & & neutral & acid $\mathrm{pH} 4.3$ & \\
\hline A. group. A.F. 1 type & 64 & $\begin{array}{l}\text { no } \\
\text { growth }\end{array}$ & $\begin{array}{l}\text { no } \\
\text { growth }\end{array}$ & $\begin{array}{l}\text { no } \\
\text { growth }\end{array}$ & $\begin{array}{l}\text { moderate } \\
\text { growth }\end{array}$ \\
\hline A.F. 100 type & 18 & $\begin{array}{l}\text { no } \\
\text { growth }\end{array}$ & $\begin{array}{l}\text { no } \\
\text { growth }\end{array}$ & $\begin{array}{l}\text { weak } \\
\text { growth }\end{array}$ & $\begin{array}{l}\text { difficult or } \\
\text { no growth }\end{array}$ \\
\hline B. group. & 4 & $\begin{array}{l}\text { good } \\
\text { growth }\end{array}$ & $\begin{array}{l}\text { no } \\
\text { growth }\end{array}$ & $\begin{array}{l}\text { no } \\
\text { growth }\end{array}$ & $\begin{array}{l}\text { moderate } \\
\text { growth }\end{array}$ \\
\hline C. group. & 8 & $\begin{array}{l}\text { good } \\
\text { growth }\end{array}$ & $\begin{array}{l}\text { good } \\
\text { growth }\end{array}$ & $\begin{array}{l}\text { good } \\
\text { growth }\end{array}$ & $\begin{array}{l}\text { good } \\
\text { growth }\end{array}$ \\
\hline
\end{tabular}

4. By the liver-Sake agar stab culture, they are also divided in 2 groups :

a) Good growth in the canal, not on the surface.
A. group, A F. 1. type 64 strains
B. group, $4 \prime \prime$
C. group, 811

b) No growth in the stab culture.

A. group, A.F. 100. type .17

5. Cell form and its arrangement: They are all slender rod, the length varies according to the medium, but the width remains constant.

In the liver-Saké culture;

$0.5-0.6 \mu \times 2-4-6 \mu$, single or $2-3$ in chain

In the yeast water culture;

generally cell elongates and curls, $0.5-0.6 \mu \times 4-10-20-40 \mu$.

In the Saké-agar stab culture;

generally cell shortens but arranges in endless chain, $0.5-0.6 \mu \times$ $1.5-2.0 \mu$.

\title{
STUDIES ON BAC. SAPROGENES SAKÉ. III.
} GROWTH OF THE BACILLI AND ITS ACCESSORY FACTOR.

$\mathrm{By}$

\section{IZUE YAMAZAKI}

(Received March 19th., 1929)

Bac. saprogenes Saké can grow in Saké but not in the usual artificial media, such as bouillon or Koji extract. 
Regarding this peculiar fact, it has long been assumed that some intimate relation should exist between some constituents of Sake and the growth of the bacilli.

Recently K. Kurono proposed a vitamin like substance, absorbable by active carbon, in Sake which is neccessary for the development of the bacilli.

The author studied on this problem and reached the following conclusions:

(1) Acid (pH. 4.3)- dextrose-bouillon when mixed with a little Saké (2-10\% by vol.) permits good growth for the bacilli.

(2) This bouillon activating factor cannot be absorbed out of Saké by active carbon, and also cannot be precipitated by any of the following reagents: that is, alcohol plus ether; basic lead acetate; $\mathrm{H}_{2} \mathrm{SO}_{4}$-phosphotungstic acid; Neuberg's soda-mercuric acetate; and $\mathrm{CuSO}_{4}-$ milk-of-lime carbohydrate precipitant.

(3) But it can be extracted by ether, in acid reaction. $0.05-0.1$ c.c. of this acidic extract can activate 10c.c. bouillon as well as Sake itself.

(4) Ether extract of long autolysed (2-6 months) yeast solution in strong acidic condition also contains this factor, 0.05-0.1c.c. of this acid extract activates 10c.c. bouillon as well as Saké extract.

(5) Thus one can cultivate the bacilli in acid-dextrose-bouillon plus yeast extract entirely free from Saké.

(6) Upon yeast water and Koji extract media, this factor is of no effect.

(7) Koji extract itself exerts much the same activating effect as Saké when added to bouillon.

(8) In Koji-extract medium itself, when it is prepared in fresh and unheated condition, most of the bacilli grow as normally and abundantly as in bouillon plus Saké medium.

(9) The above results were all well verified experimently with several decades of strains among the author's collection.

(10) The nature of the factor which controls the growth of the bacilli cannot be ascertained to be the same as that of vitamins in the animal region.

One can conclude with much certainty that the factor affects the physicochemical character of the medium so as to afford the suitable environment. 